\title{
PENGARUH PERPUTARAN KAS, PERPUTARAN PIUTANG \\ DAN PERPUTARAN PERSEDIAAN TERHADAP PROFITABILITAS
}

(Studi Pada Perusahaan Property dan Realestat

yang Terdaftar di Bursa Efek Indonesia Periode 2010-2016)

\author{
Nining Sariningsih \\ ninis760318@gmail.com
}

\section{Program Magister Manajemen, Universitas Singa Perbangsa Karawang}

\begin{abstract}
Effect of Cash Turnover, Accounts Receivable Turnover and Inventory Turnover To Profitability (Study In Company Property and Real Estate Listed on the Indonesia Stock Exchange Periode 2010-2016).
\end{abstract}

The Purpose of this research is to analyze the effect of Cash Turnover, Accounts Receivable Turnover and Inventory Turnover To Profitability (Study In Company Property and Real Estate Listed on the Indonesia Stock Exchange Periode 2010-2016).

The method applied in this research is descriptive and verificative method, due to the existence of variables which relations will be examined. This is also because this research is aimed elaborate structured, factual and accurate figures on the facts as well as the relations among researched variables that is the effect of Cash Turnover, Accounts Receivable Turnover and Inventory Turnover To Profitability.

Research was conducted in Company Property and Real Estate Listed on the Indonesia Stock Exchange Periode 2010-2016, with 17 companies as research samples.

Based on results of research data analysis show, following conclusions can be drawn :

1. Cash Turnover in partial has negative but doesn't significant effect on profitability (ROA and ROE).

2. Accounts Receivable Turnover in partial has positive and significant effect on 
profitability (ROA and $R O E)$.

3. Inventory Turnover in partial has positive and significant effect on profitability (ROA and ROE).

4. Cash Turnover, Accounts Receivable Turnover and Inventory Turnover in collectively has positive and significant effect on profitability (ROA and ROE).

5. Correlation coefficient shows that the relations among Cash Turnover, Accounts Receivable Turnover and Inventory Turnover variables To Return On Asset (ROA) are quite strong and significant. And correlation coefficient Cash Turnover, Accounts Receivable Turnover and Inventory Turnover variable To Return On Equity (ROE) are quite strong and significant.

6. Determinant coefficient show that Cash Turnover, Accounts Receivable Turnover and Inventory Turnover contribute to Return On Asset (ROA) variable as much as 20,6\% whereas $79,4 \%$ is effect by other non researched factors. And determinant coefficient show that Cash Turnover, Accounts Receivable Turnover and Inventory Turnover contribute to Return On Equity (ROE) variable as much as 33,8\% whereas 66,2\% is effect by other non researched factors.

Keywords: Cash Turnover, Accounts Receivable Turnover, Inventory Turnover, Profitability (ROA and ROE).

\begin{abstract}
ABSTRAK
Tujuan dilakukan penelitian adalah untuk menganalisis Pengaruh Perputaran Kas, Perputaran Piutang dan Perputaran Persediaan Terhadap Profitabilitas (Studi Pada Perusahaan Property dan Realestat yang Terdaftar di Bursa Efek Indonesia Periode 2010-2016).

Metode penelitian yang digunakan dalam penelitian ini adalah metode deskriptif dan verifikatif, hal ini karena terdapat variabel-variabel yang akan ditelaah hubungannya serta tujuannya untuk menyajikan gambaran secara terstruktur, factual dan akurat mengenai fakta-fakta serta hubungan antara variabel yang diteliti, yaitu Pengaruh Perputaran Kas, Perputaran Piutang dan Perputaran Persediaan Terhadap Profitabilitas.
\end{abstract}


Penelitian dilakukan pada perusahaan Sub sector Property dan realestate yang Terdaftar di Bursa Efek Indonesia Periode 2010-2016, dengan jumlah sampel sebanyak 17 perusahaan.

Dari hasil analisis data penelitian, diperoleh simpulan sebagai berikut:

1. Perputaran Kas, secara parsial berpengaruh negatif tetapi tidak signifikan terhadap Profitabilitas (ROA dan ROE).

2. Perputaran Piutang, secara parsial berpengaruh positif dan signifikan terhadap Profitabilitas (ROA dan ROE).

3. Perputaran Persediaan, secara parsial berpengaruh positif dan signifikan terhadap Profitabilitas (ROA dan ROE).

4. Perputaran Kas, Perputaran Piutang dan Perputaran Persediaan secara simultan mempunyai pengaruh positif dan signifikan terhadap Profitabilitas (ROA dan $R O E)$.

5. Koefisien korelasi menunjukan bahwa hubungan antara variabel Perputaran Kas (X1), Perputaran Piutang (X2), dan Perputaran Persediaan (X3) terhadap Return On Asset (ROA) adalah cukup kuat dan signifikan. Dan juga koefisien korelasi Perputaran Kas (X1), Perputaran Piutang (X2), dan Perputaran Persediaan (X3) terhadap Return On Equity (ROE) adalah cukup kuat dan signifikan pula.

6. Koefisien Determinasi menunjukan bahwa variabel Perputaran Kas (X1), Perputaran Piutang (X2), dan Perputaran Persediaan (X3) memberikan kontribusi terhadap Return On Asset (ROA) sebesar 20,6\% sedangkan sisanya sebesar 79,4 \% dipengaruhi oleh faktor-faktor lain yang tidak diteliti. Dan juga Koefisien Determinasi menunjukan bahwa variabel Perputaran Kas (X1), Perputaran Piutang (X2), dan Perputaran Persediaan (X3) memberikan kontribusi terhadap Return On Equity (ROE) sebesar 33,8 \% sedangkan sisanya sebesar $66,2 \%$ dipengaruhi oleh faktor-faktor lain yang tidak diteliti.

Kata Kunci: Perputaran Kas, Perputaran Piutang, Perputaran Persediaan, Profitabilitas (ROA dan ROE). 


\section{PENDAHULUAN}

\subsection{Latar Belakang Penelitian}

Dalam menghadapi era pasar bebas tantangan yang harus dihadapi oleh perusahaan akan semakin berat, tidak hanya bertujuan untuk tetap survive juga, harus mampu memiliki keunggulan dalam bersaing, dimana tujuan utama perusahaan adalah memaksimalkan nilai perusahaan (value of the firm), dan untuk mencapai kesuksesan juga berhasil memenangkan persaingan. Untuk menyikapi kondisi demikian perusahaan property dan realestat dalam mengungguli persaingan dan memperoleh keuntungan/laba yang optimal harus sukses dan mampu menggunakan aktivanya secara produktif, karena itu modal kerja sebagai salah satu komponen terpenting dari aktiva harus dikelola dan dimanfaatkan secara efektif dan produktif, sehingga mampu meningkatkan profitabilitas perusahaan.

Besar kecilnya modal kerja dapat ditambah atau dikurangi sesuai kebutuhan perusahaan. Modal kerja selalu dalam keadaan operasi atau berputar dalam perusahaan selama perusahaan yang bersangkutan dalam keadaan usaha. Periode perputaran modal kerja dimulai dari saat dimana kas diinvestasikan dalam komponen-komponen modal kerja sampai saat dimana kembali lagi menjadi kas, dimana menurut Sutrisno (2012:47) besarnya modal kerja ditentukan dengan cara menghitung perputaran elemen-elemen pembentuk modal kerja seperti perputaran kas, perputaran piutang dan perputaran persediaan. Menurut Kasmir (2011:182), menyatakan bahwa perputaran modal kerja atau working capital turn over merupakan salah satu rasio untuk mengukur atau menilai keefektifan modal kerja perusahaan selama periode tertentu. Artinya seberapa banyak modal kerja berputar selama satu periode atau dalam satu periode.

Alat analisis yang sering digunakan untuk mengetahui kinerja keuangan suatu perusahaan yaitu dengan menggunakan rasio keuangan. Rasio profitabilitas sering digunakan untuk mengukur efisiensi penggunaan modal dalam suatu perusahaan, yaitu dengan membandingkan antara laba dengan modal yang digunakan dalam operasi. Return on asset (ROA) adalah salah satu bentuk dari rasio profitabilitas yang dimaksud untuk mengukur kemampuan perusahaan dengan keseluruhan dana yang ditanamkan dalam aktiva yang digunakan untuk operasi perusahaan dalam menghasilkan keuntungan. Return 
on asset adalah rasio yang diperoleh dengan membagi laba/rugi bersih dengan total asset. Semakin tinggi nilai ROA semakin efektif pula pengelolaan aktiva perusahaan.

\subsection{Identifikasi Masalah}

Berdasarkan data, pendapat dan hasil penelitian pada latar belakang penelitian, maka yang menjadi masalah penelitian tesis ini adalah sebagai berikut :

1. Sebagian Perusahaan property dan Real Estate, yang terdapat di BEI tahun 2010-2016 masih belum efisien dalam menunjukan tingkat perputaran kasnya.

2. Perputaran kas pada Perusahaan property dan Real Estate yang terdaftar di BEI memiliki pengaruh parsial terhadap profitabilitas.

3. Sebagian Perusahaan property dan Real Estate, yang terdapat di BEI tahun 2010-2016 masih belum efisien dan efektif dalam menunjukan tingkat perputaran piutangnya.

4. Perputaran piutang pada Perusahaan property dan Real Estate yang terdaftar di BEI memiliki pengaruh parsial terhadap profitabilitas.

5. Sebagian Perusahaan property dan Real Estate, yang terdapat di BEI tahun 2010-2016 masih belum efisien dan efektif dalam menunjukan tingkat perputaran persediaannya.

6. Perputaran persediaan pada Perusahaan property dan Real Estate yang terdaftar di BEI memiliki pengaruh parsial terhadap profitabilitas.

7. Perputaran Kas, Perputaran piutang dan Perputaran persediaan pada Perusahaan property dan Real Estate yang terdaftar di BEI memiliki pengaruh simultan terhadap profitabilitas.

\subsection{Pembatasan Masalah}

Berdasarkan latar belakang masalah dan identifikasi masalah, maka penelitian ini membatasi permasalahan pada :

1. Penelitian ini hanya berkaitan dengan bidang ilmu manajemen keuangan.

2. Variable yang diteliti dalam tesis ini, dibatasi hanya pada variable perputaran kas, perputaran piutang, perputaran persediaan dan profitabilitas (ROA dan ROE).

3. Obyek penelitian ini hanya pada Perusahaan property dan realestat yang terdapat di BEI Tahun 2010 s.d. 2016. 
4. Metode analisis yang digunakan yaitu metode analisis deskriptif dan verifikatif.

5. Metode alat bantu yang digunakan, yaitu metode regresi linear berganda.

\subsection{Perumusan Masalah}

Adapun permasalahan yang akan dikemukakan penulis adalah sebagai berikut :

1. Bagaimana Perputaran Kas, Perputaran Piutang, Perputaran Persediaan pada Perusahaan property dan realestat yang terdaftar di BEI Tahun 2010 s.d. 2016.

2. Bagaimana Rasio Profitabilitas pada Perusahaan property dan realestat yang terdaftar di BEI Tahun 2010 s.d. 2016.

3. Seberapa besar pengaruh Perputaran Kas, Perputaran Piutang, Perputaran Persediaan secara parsial terhadap Rasio Profitabilitas pada Perusahaan property dan realestat yang terdaftar di BEI Tahun 2010 s.d. 2016.

4. Seberapa besar pengaruh Perputaran Kas, Perputaran Piutang, Perputaran Persediaan secara simultan terhadap Rasio Profitabilitas pada Perusahaan property dan realestat yang terdaftar di BEI Tahun 2010 s.d. 2016.

\section{TINJAUAN PUSTAKA, KERANGKA PEMIKIRAN DAN HIPOTESIS}

\subsection{Analisis Rasio Keuangan}

Analisis rasio keuangan dimaksudkan untuk menilai risiko dan peluang pada masa yang akan datang. Pengukuran dan hubungan satu pos dengan pos lain dalam laporan keuangan yang tampak dalam rasio-rasio keuangan dapat memberikan kesimpulan yang berarti dalam penentuan tingkat kesehatan keuangan suatu perusahaan.

Menurut Muslich (2004:47), analisis rasio merupakan alat analisis yang berguna apabila dibandingkan dengan rasio standar. Secara umum rasio keuangan dapat diklasifikasikan sebagai berikut:

1. Rasio Profitabilitas/Rentabilitas. Rasio yang digunakan untuk mengukur kemampuan perusahaan dalam menghasilkan keuntungan bagi perusahaan. Rasio ini antara lain:GPM (Gross Profit Margin), OPM (Operating Profit Margin), NPM (Net Profit Margin), ROA (Return to Total Asset), ROE (Return On Eqiuty). 
2. Rasio Likuiditas. Rasio ini digunakan untuk mengukur kemampuan perusahaan dalam perusahaan dalam menjamin kewajiban-kewajiban lancarnya. Rasio ini antara lain rasio kas (cash ratio), rasio cepat (quick ratio) dan rasio lancar (current ratio).

3. Rasio Pengungkit/Leverage/Solvabilitas. Rasio ini digunakan untuk mengukur tingkat pengelolaan sumber dana perusahaan. Beberapa rasio ini antara lain rasio total hutang terhadap modal sendiri, total hutang terhadap total asset, TIE (Time Interest Earned).

4. Rasio Aktivitas. Rasio yang menggambarkan aktivitas yang dilakukan perusa haan dalam menjalankan operasinya baik dalam kegiatan penjualan, pembelian, dan kegiatan lainnya. Ada dua penilaian rasio aktivitas, yaitu :

a. Rasio Nilai Pasar. Rasio yang mengukur harga pasar relative terhadap Nilai Buku Perusahaan. Rasio ini antara lain : PER (Price Earning Ratio), Devidend Yield, Deviden Payout Ratio, PBV (Price to Book Value).

b. Rasio Efesiensi/Perputaran. Rasio perputaran digunakan untuk mengukur kemampuan perusahaan dalam mengelola asset-assetnya sehingga memberikan aliran kas masuk bagi perusahaan. Rasio ini antara lain Rasio perputaran persediaan, Perputaran aktiva Tetap, dan Total Asset Turnover.

\subsection{Pengertian Rasio Profitabilitas}

Menurut Sutrisno (2012:222) rasio keuntungan digunakan untuk mengukur seberapa besar tingkat keuntungan yang dapat diperoleh perusahaan, dimana semakin besar tingkat keuntungan menunjukkan semakin baik manajemen dalam mengelola perusahaan. Tingkat profitabilitas suatu perusahaan dapat diukur dengan menggunakan rasio-rasio keuangan, yaitu :

\section{Profit Margin}

Rasio ini menggambarkan upaya untuk menekankan biaya sekecil mungkin guna mencapai keuntungan yang sebesar-besarnya, dengan membagi EAT dengan Total Pendapatan. Menurut Darsono dan Ashari (2005:56) net profit margin adalah laba bersih dibagi dengan penjualan bersih. Rasio ini menggambarkan besarnya laba bersih yang diperoleh oleh perusahaan pada setiap penjualan dilakukan. Rasio ini tidak menggambarkan besarnya persentase keuntungan bersih yang diperoleh perusahaan untuk setiap penjualan karena 
adanya unsur pendapatan dan biaya operasional. Rumusnya untuk menghitung net profit margin adalah :

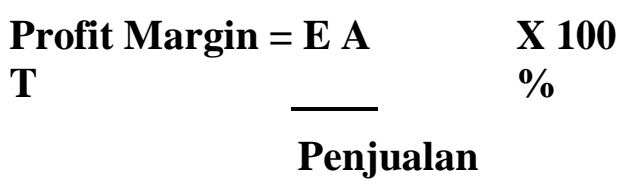

\section{Return On Asset}

Menurut Sutrisno (2012:222) mengatakan ROA juga sering disebut sebagai rentabilitas ekonomi merupakan ukuran kemampuan perusahaan dalam menghasilkan laba dengan semua aktiva yang dimiliki oleh perusahaan. Menurut Darsono dan Ashari (2005:57) return on asset menggambarkan kemampuan perusahaan untuk menghasilkan keuntungan dari setiap rupiah asset yang digunakan oleh perusahaan. Dengan mengetahui rasio ini, kita dapat menilai apakah perusahaan ini efisien dalam memanfaatkan aktivanya dalam kegiatan operasional perusahaan.

\section{Return On Asset = Laba Bersih X $100 \%$}

\section{Aktiva}

\section{Return On Equity}

Menurut Sutrisno (2012:223) mengatakan Return on equity ini sering disebut dengan rate of return on Net Worth, yaitu kemampuan perusahaan dalam menghasilkan keuntungan dengan modal sendiri yang dimiliki, sehingga ROE ada yang menyebut sebagai rentabilitas modal sendiri. Menurut Darsono dan Ashari (2005:57) return on equity adalah untuk mengukur kemampuan perusahaan untuk memperoleh keuntungan yang tersedia bagi pemegang saham. Rumus untuk menghitung Return On Equity (ROE) adalah :

$\begin{array}{ll}\begin{array}{l}\text { Return On Equity = Laba } \\ \text { Bersih }\end{array} & \begin{array}{l}X \\ 100 \%\end{array}\end{array}$

\section{Rata-rata Ekuitas}

\subsection{Pengertian Rasio Aktivitas}

Menurut Munawir (2007:240), rasio aktivitas adalah rasio untuk menilai kemampuan perusahaan dalam melaksanakan aktivitas sehari-hari atau kemampuan perusahaan dalam penjualan, penagihan piutang maupun pemanfaatan aktiva yang dimiliki. Rasio aktivitas terdiri dari beberapa macam yaitu sebagai berikut:

\section{Perputaran Persediaan (Inventory Turnover)}


Persediaaan merupakan komponen utama dari barang yang dijual, oleh karena itu semakin tinggi persediaan berputar semakin efektif perusahaan dalam mengelola persediaan. Rasio ini berguna untuk mengetahui kemampuan perusahaan dalam mengelola persediaan yang ada akan diubah menjadi penjualan.Menurut Sutrisno (2012:219), rasio perputaran persediaan merupakan komponen utama dari barang yang dijual, oleh karena itu semakin tinggi persediaan berputar semakin efektif perusahaan dalam mengelola persediaan.

\section{Harga Pokok Penjualan}

\section{Perputaran Persediaan $=$ \\ Rata-rata Persediaan}

\section{Perputaran Piutang (Receivable Turnover)}

Rasio ini menggambarkan kualitas piutang perusahaan dan kesuksesan perusahaan dalam penagihan piutang yang dimiliki. Semakin tinggi rasio ini akan semakin baik kemampuan perusahaan dalam menagih piutang yang dimiliki. Menurut Sutrisno (2012:220), rasio perputaran piutang merupakan ukuran efektifitas pengelolaan piutang. Semakin cepat perputaran piutang, maka efektif perusahaan dalam mengelola piutangnya.

\section{Penjualan Kredit}

\section{Perputaran Piutang =}

\section{Rata-rata Piutang}

\section{Perputaran Kas}

Perputaran kas "cash tumover" ialah perbandingan antara Sales dengan jumlah kas rata-rata "Riyanto (2011:95), perputaran kas merupakan kemampuan kas untuk menghasilkan pendapatan sehingga dapat dilihat berapa kali uang kas berputar dalam satu periode tertentu. Rasio ini untuk mengetahui kecepatan perputaran kas dalam periode tertentu dan dibandingkan dengan tahun berikutnya apakah terjadi peningkatan perputaran kas atau sebaliknya.

\section{Penjualan \\ Perputaran Kas \\ Rata-rata Kas}

\section{Perputaran Modal Kerja}

Rasio ini menunjukkan kemampuan modal kerja netto berputar dalam satu periode siklus kas dari perusahaan. Bila volume penjualan meningkat maka investasi dalam persediaan dan piutang juga meningkat yang berarti juga 
meningkatnya modal kerja. Menurut Kasmir (2010:225), perputaran modal kerja merupakan salah satu alat ukur untuk menentukan keberhasilan manajemen modal kerja. Dengan diketahuinya perputaran modal kerja (working capital turnover) dalam satu periode, maka akan diketahui seberapa efektif modal kerja suatu perusahaan. Jadi, dapat dikatakan bahwa perputaran modal kerja atau working capital turnover merupakan salah satu rasio untuk mengukur atau menilai keefektifannya modal kerja perusahaan selama periode tertentu. Pengukuran ini sebaiknya menggunakan dua periode atau lebih sebagai data pembanding, sehingga memudahkan dalam menilainya.

\section{Penjualan Bersih}

Perputaran Modal Kerja =

\section{Modal Kerja ( netto)}

\section{Perputaran total aktiva (Assets Turnover)}

Merupakan ukuran efektifitas pemanfaatan aktiva dalam menghasilkan penjualan. Semakin besar perputaran total aktiva semakin efektif perusahaan mengelola aktivanya.

\section{Penjualan Bersih}

Perputaran total aktiva $=$

\section{Total Aktiva}

\subsection{Hipotesis Penelitian}

Hipotesis merupakan jawaban sementara terhadap rumusan masalah penelitian, oleh karena itu rumusan masalah penelitian biasanya disusun dalam bentuk pertanyaan. Dari kerangka pemikiran dan landasan teori yang telah dikemukakan sebelumnya, maka hipotesis yang dikemukakan adalah sebagai berikut:

1. Terdapat pengaruh positif perputaran kas, perputaran piutang, dan perputaran persediaan secara parsial terhadap profitabilitas (ROA dan ROE) pada perusahaan property dan realestat yang terdaftar di BEI Tahun 2010 s.d. 2016.

2. Terdapat pengaruh positif perputaran kas, perputaran piutang, dan perputaran persediaan secara simultan terhadap profitabilitas (ROA dan ROE) pada perusahaan property dan realestat yang terdaftar di BEI Tahun 2010 s.d. 2016.

3.

\section{METODE PENELITIAN}

Metode penelitian yang akan digunakan dalam penelitian ini adalah metode deskriptif dan verifikatif.Populasi dalam penelitian ini yaitu perusahaan property dan realestat yang dipublikasikan yang terdaftar di Bursa Efek Indonesia 
tahun 2010 sampai dengan 2016, sebanyak 45 perusahaan. Sampel pada penelitian ini sebanyak 17 perusahaan property dan realestat. Penentuan jumlah data menggunakan populasi dalam penelitian yaitu laporan keuangan tahunan perusahaan property dan realestat selama periode tahun 2010 sampai dengan 2016, sejumlah 119 data. Data laporan keuangan yang diperlukan mencakup data tahun 2010 sampai dengan 2016.

Dalam penelitian ini terdapat variabel bebas (independen variabel) dan variabel terikat (dependen variabel). Variabel bebas adalah variabel yang nilainya tidak bergantung dari variabel yang lain dan variabel terikat adalah variabel yang nilainya tergantung dari variabel yang lain, variabel terikatnya adalah $(\mathrm{Y})$ :

Profitabilitas (ROA dan ROE), variabel bebasnya adalah (X1) adalah perputaran Kas, (X2) adalah perputaran piutang, (X3) adalah perputaran persediaan. Persamaan sumber dari Sugiyono (2010: 257) sebagai berikut : Regresi Berganda $: \mathrm{Y}=\alpha+\beta 1 \mathrm{X} 1+\beta 2 \mathrm{X} 2+\beta 3 \mathrm{X} 3+\mathrm{e}$

Dimana :

$$
\begin{aligned}
& \text { Y : Profitabilitas (ROA dan ROE) } \\
& \mathrm{X} 1 \text { : Perputaran Kas } \\
& \text { X2 : Perputaran Piutang } \\
& \text { X3 : Perputaran Persediaan } \\
& \alpha \quad \text { : Konstanta } \\
& \beta \text { : Koefisien } \\
& \text { Regresi e : Variabel } \\
& \text { residual }
\end{aligned}
$$

\section{HASIL PENELITIAN DAN PEMBAHASAN}

\subsection{Uji Multikolinieritas}

Dari hasil uji multikolinearitas diperoleh angka VIF ada di bawah 10 $(\mathrm{X} 1=1.009, \mathrm{X} 2=1.010, \mathrm{X} 3=1.013)$. Demikian juga nilai TOLERANCE berada di atas $0,10(X 1=0.991, X 2=0.990, X 3=0.987)$. Dengan demikian dapat disimpulkan bahwa model regresi tersebut tidak terdapat problem multikolinieritas baik berdasarkan pada besara VIF maupun besaran korelasi antar variabel. 


\subsection{Uji Heterokedastisitas}

Dari hasil uji Heterokedastisitas diketahui bahwa titik-titik menyebar secara acak, tidak membentuk sebuah pola tertentu yang jelas, serta tersebar baik di atas maupun di bawah angka 0 pada sumbu Y. Hal ini berarti tidak terjadi heteroskedastisitas pada model regresi tersebut, sehingga model regresi layak dipakai untuk prediksi variabel $\mathrm{ROA}(\mathrm{Y})$ dan $\mathrm{ROE}(\mathrm{Y})$ berdasarkan masukan variabel perputaran kas (X1), perputaran piutang (X2), dan perputaran persediaan (X3).

\subsection{Analisis Regresi Sederhana (Pengaruh Parsial)}

Perputaran Kas, Perputaran Piutang dan Perputaran Persediaan terhadap ROA

\begin{tabular}{|c|c|c|c|c|c|}
\hline No & Pengaruh Parsial & $\mathrm{r}$ & $\begin{array}{l}\mathrm{t} \\
\text { hitung }\end{array}$ & $\begin{array}{r}\mathrm{T} \\
(5 \%) \\
\text { (two } \\
\text { tail) }\end{array}$ & Kesimpulan \\
\hline 1 & $\begin{array}{ll}\text { Perputaran } & \\
\text { Kas } & \text { terhadap } \\
\text { ROA } & \end{array}$ & 0,045 & $-0,492$ & 1,980 & $\begin{array}{l}\text { HO.1 diterima dan HI. } \\
\text { ditolak }\end{array}$ \\
\hline 2 & $\begin{array}{l}\text { Perputaran Piutang } \\
\text { terhadap } \\
\text { ROA }\end{array}$ & 0,417 & 4,956 & 1,980 & $\begin{array}{l}\text { HO.2 ditolak dan HI.2 } \\
\text { diterima }\end{array}$ \\
\hline 3 & $\begin{array}{lr} & \text { Persedia } \\
\text { Perputaran } & \text { an } \\
\text { terhadap } & \\
\text { ROA } & \end{array}$ & 0,209 & 2,313 & 1,980 & $\begin{array}{l}\text { HO.3 ditolak dan HI.3 } \\
\text { diterima }\end{array}$ \\
\hline
\end{tabular}


Perputaran Kas, Perputaran Piutang dan Perputaran Persediaan terhadap ROE

\begin{tabular}{|c|c|c|c|c|c|}
\hline No & Pengaruh Parsial & $r$ & hitung & $\begin{array}{r}\mathrm{T} \\
(5 \%) \\
\text { (two } \\
\text { tail) }\end{array}$ & Kesimpulan \\
\hline 1 & $\begin{array}{ll}\text { Perputaran } & \\
\text { Kas } & \text { terhadap } \\
\text { ROE } & \end{array}$ & 0,041 & $-0,442$ & 1,980 & $\begin{array}{l}\text { HO.1 diterima dan HI. } \\
\text { ditolak }\end{array}$ \\
\hline 2 & $\begin{array}{l}\text { Perputaran Piutang } \\
\text { terhadap } \\
\text { ROE }\end{array}$ & 0,512 & 6,452 & 1,980 & $\begin{array}{l}\text { HO.2 ditolak dan HI.2 } \\
\text { diterima }\end{array}$ \\
\hline 3 & $\begin{array}{lr}\text { Perputaran } & \text { Persedia } \\
\text { terhadap } & \text { an } \\
\text { ROE } & \end{array}$ & 0,314 & 3,576 & 1,980 & $\begin{array}{l}\text { HO.3 ditolak dan HI.3 } \\
\text { diterima }\end{array}$ \\
\hline
\end{tabular}

Berdasarkan hasil analisis pengujian hipotesis parsial table 4.27 dan 4.28 diketahui bahwa variabel Perputaran Piutang (X2) dan Perputaran Persediaan (X3) secara mandiri (parsial) berpengaruh positif dan signifikan terhadap Return On Asset (ROA) dan Return On Equity (ROE) sedangkan Perputaran Kas (X1), mempunyai pengaruh negatif tetapi tidak signifikan.

Secara parsial adanya kenaikan pada Perputaran Piutang (X2) dan Perputaran Persediaan (X3) pada seluruh perusahaan yang diteliti secara signifikan dapat meningkatkan Return On Asset (ROA) dan Return On Equity

$(R O E)$ atau sebaliknya. Sedangkan Perputaran Kas (X1) secara parsial apabila terjadi penambahan pada seluruh perusahaan yang diteliti mempunyai pengaruh negative tetapi tidak signifikan terhadap Return On Asset (ROA) dan Return On Equity (ROE) atau sebaliknya. 


\section{Pengujian Pengaruh Simultan}

Tabel 4.29 Uji Pengaruh Simultan Uji F

Perputaran Kas, Perputaran Piutang dan Perputaran Persediaan terhadap ROA ANOVA $^{\text {b }}$

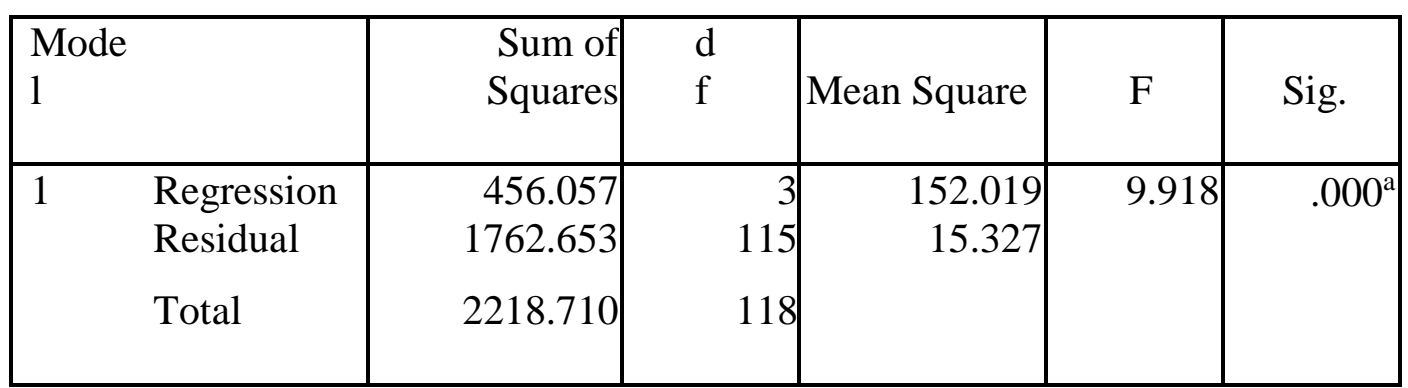

a. Predictors: (Constant), Perputaran Persediaan, Perputaran Kas, Perputaran Piutang

b. Dependent Variable: ROA

Tabel 4.30 Uji Pengaruh Simultan Uji F

Perputaran Kas, Perputaran Piutang dan Perputaran Persediaan terhadap ROE

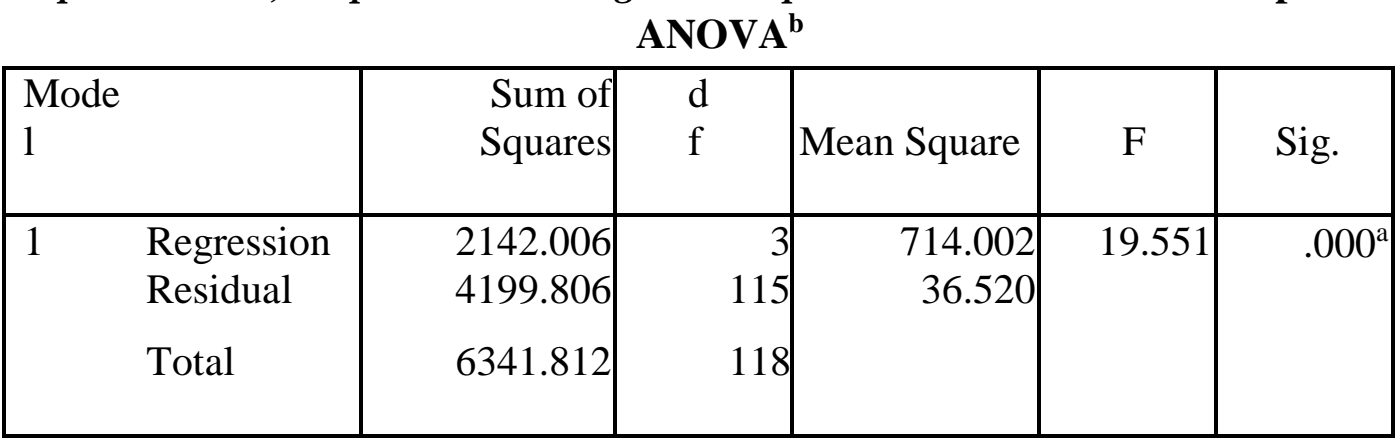

a. Predictors: (Constant), Perputaran Persediaan, Perputaran Kas, Perputaran Piutang

b. Dependent Variable: ROE

a. Pengujian ANOVA

Berdasarkan table 4.29 dan 4.30, maka dilakukan analisis sebagaimana dijelaskan pada table 4.31 dan 4.32 di bawah ini. 
Tabel 4.31 Pengujian Pengaruh Berganda

Perputaran Kas, Perputaran Piutang dan Perputaran Persediaan terhadap ROA

\begin{tabular}{|lr|r|c|lrl|}
\hline Pengaruh Simultan & F hitung & $\begin{array}{c}\text { F } \\
\text { tabel } \\
(5 \%)\end{array}$ & \multicolumn{3}{|c|}{ Kesimpulan } \\
& & & & & \\
\hline $\begin{array}{lr}\text { Perputaran } \\
\text { Perputaran }\end{array}$ & Piutang, \\
dan & 9,918 & 2,68 & Perputaran & Kas, & Perputaran \\
Perputaran & & & $\begin{array}{l}\text { Piutang } \\
\text { dan }\end{array}$ & Perputaran \\
& & & & secara & simultan \\
\hline
\end{tabular}

\begin{tabular}{|l|l|l|l|}
\hline $\begin{array}{l}\text { Persediaan terhadap } \\
\text { ROA }\end{array}$ & & & $\begin{array}{l}\text { berpengaruh sangat signifikan } \\
\text { terhadap Return On Asset (ROA) }\end{array}$ \\
\hline
\end{tabular}

Tabel 4.31 Pengujian Pengaruh Berganda

Perputaran Kas, Perputaran Piutang dan Perputaran Persediaan terhadap ROE

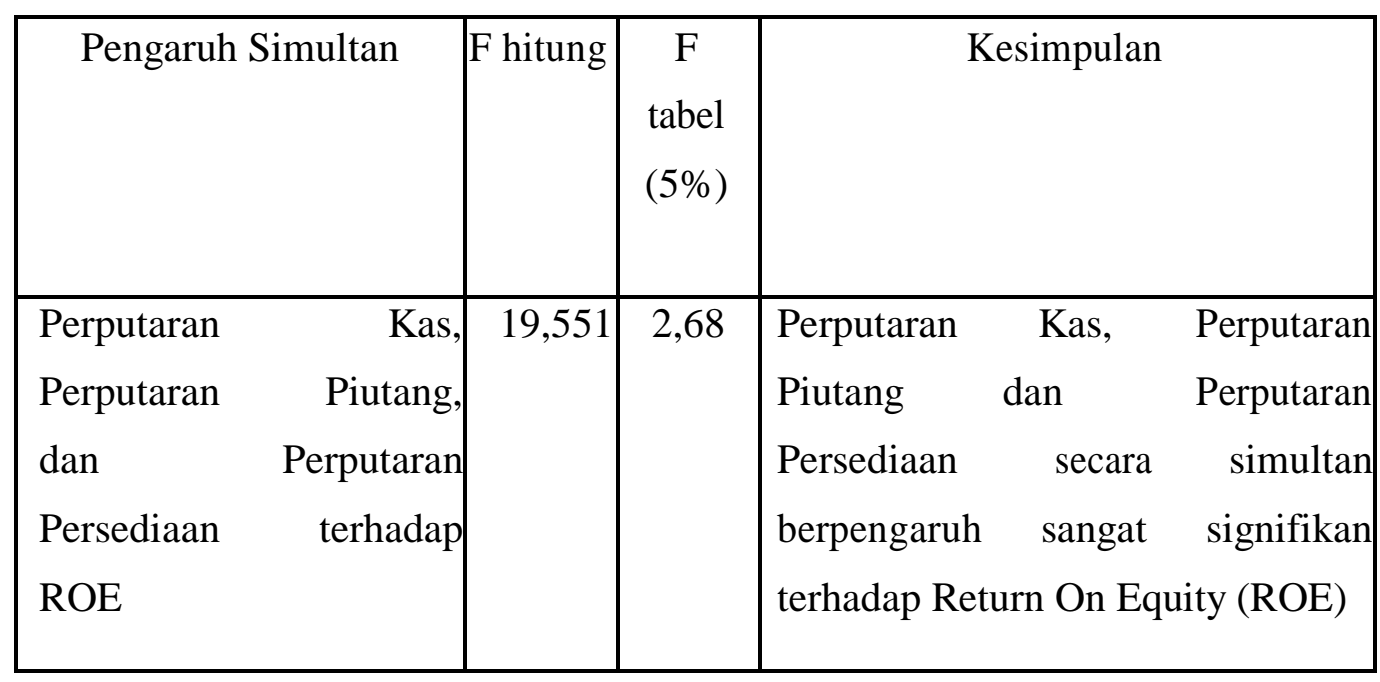


Berdasarkan table di atas diperoleh F hitung sebesar 9,918 dan 19,551 lebih besar dari F table $(0,05)$ sebesar 2,68 maka HO ditolak atau HI diterima secara signifikan berarti Perputaran Kas, Perputaran Piutang dan Perputaran Persediaan secara bersama-sama memiliki pengaruh yang signifikan terhadap perubahan Return On Asset (ROA) dan Return On Equity (ROE).

\subsection{Pembahasan Penelitian}

Berdasarkan hasil penelitian dan uraian di atas berikut akan dibahas mengenai :

1. Perputaran Kas, Perputaran Piutang, Perputaran Persediaan pada perusahaan property dan realestate yang terdaftar di BEI tahun 20102016.

a. Perputaran Kas

Rata-rata Perputaran Kas dari tahun 2010 sampai 2016 adalah 3,2397 sedangkan nilai maksimum untuk variabel Perputaran Kas adalah sebesar 16,16 yang terjadi tahun 2016 pada PT.Cowell Development Tbk.

\section{b. Perputaran Piutang}

Rata-rata Perputaran Piutang dari tahun 2010 sampai 2016 adalah 11,9771 sedangkan nilai maksimum untuk variabel Perputaran Piutang adalah sebesar 49,18 yang terjadi pada tahun 2012 pada PT.Summarecon Agung Tbk.

c. Perputaran Persediaan.

Rata- rata Perputaran Persediaan dari tahun 2010 sampai 2016 adalah sebesar 0,5652, sedangkan nilai maksimum untuk variabel Perputaran Persediaan adalah sebesar 2,60 yang terjadi pada tahun 2015 pada PT.Kawasan Industri Jababeka Tbk. 
2. Return On Asset (ROA) dan Return On Equity (ROE) pada perusahaan property dan realestate yang terdaftar di BEI tahun 2010-2016.

a. Return On Asset (ROA).

Rata-rata Return On Asset (ROA) dari tahun 2010 sampai 2016 adalah sebesar 5,1851 sedangkan nilai maksimum untuk variabel Return On Asset (ROA) adalah sebesar 24,06 yang terjadi pada tahun 2015 pada PT.Lamicitra Nusantara Tbk.

b. Return On Equity (ROE).

Rata-rata Return On Equity (ROE) dari tahun 2010 sampai 2016 adalah sebesar 9,1539 sedangkan nilai maksimum untuk variabel Return On Equity (ROE) adalah sebesar 31,38 yang terjadi pada tahun 2014 pada PT.Pakuwon Jati Tbk.

3. Pengaruh Perputaran Kas, Perputaran Piutang, Perputaran Persediaan secara parsial terhadap Return On Asset (ROA) dan Return On Equity $(R O E)$ pada perusahaan property dan realestate yang terdaftar di BEI tahun 2010-2016.

a. Perputaran Kas

Berdasarkan hasil penelitian secara parsial diperoleh bahwa Perputaran Kas berpengaruh negatif terhadap Return On Asset (ROA), tetapi hubungannya sangat rendah $(\mathrm{r}=0,045)$. Perputaran Kas berpengaruh negative tidak signifikan dalam mengurangi Return On Asset (ROA), secara parsial sebesar 0,2\% dengan demikian masih ada 99,8 \% faktor lain yang mempengaruhi perubahan Return On Asset (ROA). Dan Perputaran Kas berpengaruh negatif terhadap Return On Equity (ROE) tetapi hubungannya sangat rendah $(\mathrm{r}=0,041)$ Perputaran Kas berpengaruh negatif tidak signifikan dalam mengurangi Return On Equity (ROE), secara parsial sebesar 0,2 \% dengan demikian masih ada 99,8\% faktor lain yang mempengaruhi perubahan Return On Equity (ROE).

b. Perputaran Piutang 
Berdasarkan hasil penelitian secara parsial diperoleh bahwa Perputaran Piutang berpengaruh positif terhadap Return On Asset (ROA) dan hubungannya cukup kuat $(\mathrm{r}=0,417)$. Perputaran Piutang berpengaruh positif dan signifikan dalam meningkatkan Return On Asset (ROA), secara parsial sebesar $17,4 \%$ dengan demikian masih ada $82,6 \%$ faktor lain yang mempengaruhi perubahan Return On Asset (ROA). Dan Perputaran Piutang berpengaruh positif terhadap Return On Equity (ROE) dan mempunyai hubungan yang cukup kuat $(\mathrm{r}=0,512)$. Perputaran Piutang berpengaruh positif dan signifikan dalam meningkatkan Return On Equity (ROE), secara parsial sebesar 26,2 \% dengan demikian masih ada 73,8\% faktor lain yang mempengaruhi perubahan Return On Equity (ROE).

c. Perputaran Persediaan

Berdasarkan hasil penelitian secara parsial diperoleh bahwa Perputaran Persediaan berpengaruh positif terhadap Return On Asset (ROA) tetapi hubungannya rendah $(\mathrm{r}=0,209)$. Perputaran Persediaan berpengaruh positif dan signifikan dalam meningkatkan Return On Asset (ROA), secara parsial sebesar 4,4\% dengan demikian masih ada 95,6 \% faktor lain yang mempengaruhi perubahan Return On Asset (ROA). aDan Perputaran Persediaan pun berpengaruh positif terhadap Return On Equity (ROE) tetapi hubungannya rendah $(\mathrm{r}=0,314)$. Perputaran Persediaan berpengaruh signifikan dalam meningkatkan Return On Equity (ROE), secara parsial sebesar 9,9\% dengan demikian masih ada 90,1\% faktor lain yang mempengaruhi perubahan Return On Equity (ROE).

4. Pengaruh Perputaran Kas, Perputaran Piutang, Perputaran Persediaan secara simultan terhadap Return On Asset (ROA) dan Return On Equity $(R O E)$ pada perusahaan property dan realestate yang terdaftar di BEI tahun 2010-2016.

a. Berdasarkan hasil uji diperoleh :

1) Multiple regression (r) adalah 0,453 artinya pengaruh (korelasi) menunjukan bahwa hubungan antara variabel Perputaran Kas (X1), Perputaran Piutang (X2), dan Perputaran Persediaan (X3) terhadap Return On Asset (ROA) adalah cukup kuat. Koefisien Determinasi = 0,206 atau 20,6\%. Hal ini menjelaskan bahwa kontribusi terhadap 
Return On Asset (ROA) sebesar 20,6 \% sedangkan sisanya sebesar 79,4

$\%$ dipengaruhi oleh faktor-faktor lain yang tidak diteliti.

2) Dan dari hasil uji tersebut diperoleh juga multiple regression (r) adalah 0,581 artinya pengaruh (korelasi) membuktikan bahwa hubungan antara variabel Perputaran Kas (X1), Perputaran Piutang (X2), dan Perputaran Persediaan (X3) terhadap Return On Equity (ROE) adalah cukup kuat. Koefisien Determinasi $=0,338$ atau 33,8 \%. Hal ini menjelaskan bahwa kontribusi terhadap Return On Equity (ROE) sebesar 33,8 \% sedangkan sisanya sebesar 66,2\% dipengaruhi oleh faktor-faktor lain yang tidak diteliti.

b. Berdasarkan hasil uji diperoleh :

1) Pengaruh Perputaran Kas, Perputaran Piutang, Perputaran Persediaan secara simultan terhadap Return On Asset (ROA) diperoleh F hitung sebesar 9,918 lebih besar dari F table $(0,05)$ sebesar 2,68, maka HO ditolak atau HI diterima secara signifikan berarti Perputaran Kas, Perputaran Piutang dan Perputaran Persediaan secara bersamasama memiliki pengaruh yang signifikan terhadap perubahan Return On Asset (ROA).

2) Pengaruh Perputaran Kas, Perputaran Piutang, Perputaran Persediaan secara simultan terhadap Return On Equity (ROE), diperoleh F hitung sebesar 19,551 lebih besar dari F table $(0,05)$ sebesar 2,68, maka HO ditolak atau HI diterima secara signifikan berarti Perputaran Kas, Perputaran Piutang dan Perputaran Persediaan secara bersama-sama memiliki pengaruh yang signifikan terhadap perubahan Return On Equity (ROE).

\section{SIMPULAN DAN SARAN}

\subsection{Simpulan}

Berdasarkan hasil penelitian dan pembahasan pada bab-bab sebelumnya dapat dikemukakan beberapa kesimpulan sebagai berikut :

1. Perputaran Kas, Perputaran Piutang, Perputaran Persediaan pada perusahaan property dan realestate yang terdaftar di BEI tahun 20102016. 
a. Rata-rata Perputaran Kas yang paling tinggi dicapai oleh PT.Perdana Gapuraprima Tbk.yaitu sebesar 9,29. Sedangkan rata-rata Perputaran Kas yang paling rendah diperoleh PT. Duta Pertiwi Tbk. dan PT.Ristia Bintang Mahkotasejati Tbk yaitu sebesar 1,27.

b. Rata-rata Perputaran Piutang yang paling tinggi dicapai oleh PT.Summarecon Agung Tbk. yaitu sebesar 34,85. Sedangkan rata-rata Perputaran Piutang yang paling rendah diperoleh PT.Megapolitan Developments Tbk. yaitu sebesar 1,72.

c. Rata-rata Perputaran Persediaan yang paling tinggi dicapai oleh PT.Kawasan Industri Jababeka Tbk. yaitu sebesar 1,69. Sedangkan ratarata Perputaran Persediaan yang paling rendah diperoleh PT.Sentul City Tbk. yaitu sebesar 0,17.

2. Rasio Profitabilitas (Return On Asset (ROA) dan Return On Equity (ROE) ) pada perusahaan property dan realestate yang terdaftar di BEI tahun 2010-2016.

a. Return On Asset (ROA) pada perusahaan sektor property dan realestate selama periode tahun 2010 sampai dengan tahun 2016 mengalami perkembangan yang fluktuatif. Rata-rata Return On Asset yang paling tinggi dicapai oleh PT.Metropolitan Land Tbk. yaitu sebesar 10,95. Sedangkan rata-rata Return On Asset yang paling rendah (negative) diperoleh PT.Bukit Darmo Property Tbk.yaitu sebesar $(3,35)$.

b. Return On Equity (ROE) pada perusahaan sektor property dan realestate selama periode tahun 2010 sampai dengan tahun 2016 mengalami perkembangan yang fluktuatif. Rata-rata Return On Asset yang paling tinggi dicapai oleh PT.Pakuwon Jati Tbk. yaitu sebesar 20,88. Sedangkan rata-rata Return On Equity yang paling rendah (negative) diperoleh PT.Bukit Darmo Property Tbk.yaitu sebesar $(4,71)$.

3. Pengaruh Perputaran Kas, Perputaran Piutang, Perputaran Persediaan secara parsial terhadap Return On Asset (ROA) dan Return On Equity $(R O E)$ pada perusahaan property dan realestate yang terdaftar di BEI tahun 2010-2016.

Berdasarkan hasil penelitian diperoleh bahwa Perputaran Piutang dan Perputaran Persediaan secara parsial berpengaruh positif dan signifikan terhadap Return On Asset (ROA) dan Return On Equity (ROE), sedangkan 
Perputaran Kas secara parsial berpengaruh negatif tetapi tidak signifikan terhadap Return On Asset (ROA) dan Return On Equity (ROE).

4. Pengaruh Perputaran Kas, Perputaran Piutang, Perputaran Persediaan secara simultan terhadap Return On Asset (ROA) dan Return On Equity $(R O E)$ pada perusahaan property dan realestate yang terdaftar di BEI tahun 2010-2016.

a. Koefisien korelasi menunjukan bahwa hubungan antara variabel Perputaran Kas (X1), Perputaran Piutang (X2), dan Perputaran Persediaan (X3) terhadap Return On Asset (ROA) sebesar 0,453 artinya mempunyai pengaruh cukup kuat. Dan juga koefisien korelasi Perputaran Kas (X1), Perputaran Piutang (X2), dan Perputaran Persediaan (X3) terhadap Return On Equity (ROE) diperoleh sebesar 0,581 artinya mempunyai pengaruh cukup kuat pula.

b. Koefisien Determinasi menunjukan bahwa variabel Perputaran Kas (X1), Perputaran Piutang (X2), dan Perputaran Persediaan (X3) memberikan kontribusi terhadap Return On Asset (ROA) sebesar 20,6 \%. sedangkan sisanya sebesar 79,4\% dipengaruhi oleh faktor-faktor lain yang tidak diteliti. Dan juga Koefisien Determinasi menunjukan bahwa variabel Perputaran Kas (X1), Perputaran Piutang (X2), dan Perputaran Persediaan (X3) memberikan kontribusi terhadap Return On Equity (ROE) sebesar 33,8\% sedangkan sisanya sebesar 66,2\% dipengaruhi oleh faktor-faktor lain yang tidak diteliti.

c. Berdasarkan hasil penelitian Perputaran Kas, Perputaran Piutang, dan Perputaran Persediaan secara simultan mempunyai pengaruh positif yang signifikan terhadap Profitabilitas (Return On Asset (ROA) dan Return On Equity (ROE)).

\subsection{Saran}

Berdasarkan hasil simpulan dan pembahasan diatas maka peneliti menyarankan agar perusahaan property dan realestate yang terdaftar di BEI tahun 2010-2016, dalam meningkatkan Profitabilitas (Return On Asset (ROA) dan Return On Equity (ROE)), dengan beberapa cara sebagai berikut :

1. Meningkatkan Penjualan dan penggunaan kas yang efektif dan efisien. 
2. Meningkatkan atau mengefektifkan dalam menagih piutang yang dimiliki perusahaan.

3. Efektif dan efisien dalam pemanfaatan dan pengelolaan persediaan perusahaan.

4. Efektif dan efisien dalam pemanfaatan faktor-faktor lain yang tidak diteliti, yang dimungkinkan mempunyai pengaruh signifikan yaitu aktiva tetap, biaya operasional perusahaan dan penjualan.

Dan untuk penelitian yang akan datang peneliti bisa meneliti faktor-faktor lain yang dimungkinkan mempengaruhi Return On Asset (ROA) dan Return On Equity $(R O E)$ yaitu aktiva tetap, biaya operasional perusahaan dan penjualan.

\section{DAFTAR PUSTAKA}

\section{Buku}

Sutrisno, 2012. Manajemen Keuangan Teori Konsep dan Aplikasi. Penerbit Ekonisia, Yogyakarta.

Brigham Houston, 2010. Dasar-dasar Manajemen Keuangan. Salemba Empat, Jakarta

Suad Husnan, Enny Pudjiastuti. 2012. Dasar-dasar Manajemen Keuangan. UPP STIM YKPN, Yogyakarta.

Bambang Riyanto, 2008. Dasar-dasar Pembelajaran Perusahaan, BPFE, Yogyakarta.

Agnes Sawir, 2009. Analisa Kinerja Keuangan dan Perencanaan keauangan Perusahaan, PT. Gramedia Pustaka Utama, Jakarta.

Lukman Syamsuddin, 2001. Manajemen Keuangan Perusahaan, PT. Raja Grafindo Persada, Jakarta.

Kasmir, 2008, Analisis Laporan Keuangan, Rajawali Pers, Jakarta.

Irham Fahmi, 2013. "Pengantar Manajemen Keuangan Teori dan Soal jawab”. Cetakan Kedua. Bandung: Alfabeta. 
